\title{
A STUDY ON THE QUALITY OF ORGANIC HENS EGGS IN THE EGYPTIAN MARKET
}

H.F, Ahmed'; Azza, M. K. Sobeih; Seham, N. Homouda ${ }^{2}$ and Amal, F. Elbanna

${ }^{1}$ Department of Food Control, Faculty of Veterinary Medicine, Kafrelsheikh University,.

${ }^{2}$ Department of food hygiene, Animal Health Research Institute, Tanta Laboratory.

\section{ABESTRACT}

A study on 200 organic eggs samples from Egyptian markets was conducted in order to evaluate the physical quality and the microbial load of the organic hens egg. The study revealed that $45 \%$ of the examined organic eggs had dirty shell, 9\% Rough shell and $4.5 \%$ of bad odours. The microbiological examination showed that the average total aerobic bacterial, total coliforms and total staphylococcus count of shell were $1.6 \times 106 \pm 3.2 \times 105,3.9 \times 104 \pm$ $3.9 \times 103$ and $5.8 \times 105 \pm 4.8 \times 104$, respectively. While the average total aerobic bacterial, total coliforms and total staphylococcus counts of egg content samples were $2.7 \times 103 \pm 4 \times 102,8.1 \times 10 \pm 1.5 \times 10$ and $8.5 \times 102 \pm 1.6 \times 10$, respectively. Staphylococcus aureus and salmonellae were isolated from $7 \%$ and $1.5 \%$ of the examined egg shell samples. While both organisms could not be isolated from the egg content of the examined organic egg samples. The public health 
and economic importance of isolated microorganisms were discussed.

\section{INTRODUCTION}

Organic egg is product that has been produced in accordance with organic standards and has lower levels of veterinary drugs and pesticides. Also the 'organic' label provides assurance to consumers that no food ingredient has been subject to irradiation and that genetically modified organisms have been excluded (Kouba, 2003).

In recent years, raising demand for organic food has been noticed. According to the majority of consumers it is safe for the health, tastefulness also its benefits are nutritional value. In addition the majority of consumers have lost some trust in food derived from conventional due to the use of developing technology and policies for the intensive input use for the supply of the food necessities. Furthermore the production of organic food based on special standards is considered as environmentally friendly and devoid of artificial fertilizers (Kouba, 2003; Newerli-Guz and Śmiechowska, 2004).

Organic poultry cannot be given growth producing hormones, but may receive preventive medical care such as vaccines, and dietary supplements of vitamins and minerals. They must be fed on certified organic feed, free of animal byproducts, or feed on certified organic pasture if raised on pasture system. Hens must have free access to out door, shade, exercise areas, fresh air and direct sun light suitable to their age and stage of production. Also organic egg must be processed in 
plants that are certified to process organic egg (Henry, 2002 and USDA, 2009).

A characteristic of organic animal keeping systems is a strict limitation of drug application (antibiotics). This may lead to higher incidence of pathogens, particularly zoonotic bacteria. On the other hand, these strong restrictions, together with exclusive usage of in-house produced feeding stuff and fertilization with antibiotic-free manure, are supposed to influence the resistance of bacteria, in which the resistance rates ought to be lower in organic farms than conventional one. (Schwaiger, et al 2008).

\section{MATERIALS AND METHODS}

\section{Collection of Samples:}

A total of 200 organic hens eggs samples (each sample was 3 eggs) were collected from different Egyptian supermarkets, and transferred as soon as possible to the laboratory with a minimum of delay for examination. Eggs with cracked shell or leaker were excluded.

2. Physical Examination (Vaclavik and Christian, 1998):

The collected eggs were visually examined for cleanliness, roughness and odour.

\section{3. bacteriological examination:}

\subsection{Preparation of samples:}

a) Egg shell (Harrigan,1998):

The eggs were grouped mainly in pools of 3.The eggs were soaked in $120 \mathrm{ml}$ sterile buffered peptone water $1 \%(40 \mathrm{ml}$ for each) in a sterile 
bag. Subsequently, the eggs were rubbed gently through the bag for a minute. Ten fold serial dilutions were prepared from the prepared buffered peptone water for the bacteriological examination.

b) Egg content (Harrigan,1998):

The eggs were then surface sterilized by spraying them with alcohol and flamed quickly. Then the content of 3 eggs were evacuated aseptically into a sterile bag and homogenized. Twenty-five grams of the homogenate were transferred into $225 \mathrm{ml}$ peptone water dilution blank and shaken to prepare tenth dilution, from this ten fold serial dilution were prepared.

\subsection{Determination of total aerobic bacterial count (APHA, 2004):}

One milliliter from each of the previously prepared serial dilutions was transferred aseptically into each of duplicate sterile Petri dishes. About $10-12 \mathrm{ml}$ of sterile melted and cooled at $\left(45 \pm 1{ }^{\circ} \mathrm{C}\right)$ standard plate count agar medium were poured into each plate and mixed carefully. After solidification, the inoculated plates including control one (inoculated with sterile distal water) incubated at $32 \pm 1^{\circ} \mathrm{C}$ for $48 \pm 3 \mathrm{hrs}$.

\subsection{Determination of Coliforms count MPN/g (APHA, 2004):}

One $\mathrm{ml}$ from each of the prepared serial dilutions was inoculated into a series of three fermentation tubes containing Lauryl Sulphate Tryptose (LST) broth supplemented with inverted Durham's tubes. Inoculated tubes, as well as, the control were incubated at $35^{\circ} \mathrm{C}$ for $48 \mathrm{hrs}$.

\subsection{Determination total Staphylococci Count (ISO, 2003):}


On each of duplicate plates of Baird-Parker's agar, $0.1 \mathrm{~mL}$ from each of the previously prepared serial dilutions was plated and spread on the surface of the agar by using a sterile bent glass rod and incubated at $37^{\circ} \mathrm{C}$ for $48 \mathrm{hrs}$.

\subsection{Isolation and identification of $S$. aureus:}

Suspected colonies of $S$. aureus which appear as black shiny colonies with white margins and surrounded by clear zone extending into opaque medium were subjected for further identification according to (FDA, 1998a).

\subsection{Isolation and identification of salmonellae (APHA, 2004):}

Twenty five $g$ of the prepared sample was aseptically added to 225 $\mathrm{mL}$ of sterile buffered peptone water, thoroughly mixed and incubated for $24 \pm 2 \mathrm{hrs}$ at $35 \pm 1^{\circ} \mathrm{C}$ after that $1 \mathrm{~mL}$ was inoculated into sterile tubes containing $10 \mathrm{~mL}$ Selenite $\mathrm{F}$ broth and incubated at $35 \pm 1^{\circ} \mathrm{C}$ for 24 \pm 2 hrs. A loopful from the selective enrichment broth was streaked on two plates of Xylose lysine deoxycholate (XLD) agar medium and incubated at $35^{\circ} \pm 1 \mathrm{C}$ for $24 \pm 2 \mathrm{hrs}$. Colonies suspected to be salmonella were purified for further identification according to $(\boldsymbol{F D A}, \mathbf{1 9 9 8 b})$.

\section{RESULTS}

Table (1): Physical characteristics of organic hens eggs shell samples $(n=200)$.

\begin{tabular}{|c||c|c|}
\hline \multirow{2}{*}{ Shell Defects } & \multicolumn{2}{|c|}{ Positive samples } \\
\cline { 2 - 3 } & No & $\% *$ \\
\hline \hline Dirty shell & 90 & 45 \\
\hline \hline
\end{tabular}

$\overline{\text { Kafrelsheikh Vet. Med. J. Vol. } 14 \text { No. } 1 \text { (2016) }}$ 


\begin{tabular}{||c||c||c||}
\hline \hline Rough shell & 18 & 9 \\
\hline Bad odour & 9 & 4.5 \\
\hline Total & 117 & 58.5 \\
\hline
\end{tabular}

*The percentages were calculated according to the total number of samples.

Table (2): Statistical analytical results of bacteriological counts in the examined organic egg shell samples $(n=200)$.

\begin{tabular}{|c|c|c|c|c|c|}
\hline \multirow{2}{*}{ Bacterial counts } & \multicolumn{2}{|c|}{ Positive Samples } & \multirow{2}{*}{ Min } & \multirow{2}{*}{ Max } & \multirow{2}{*}{ Mean \pm SEM } \\
\hline & No & $\%$ & & & \\
\hline$\overline{\mathrm{TABC}}$ & $\overline{200}$ & $\overline{100}$ & $5.5 \times 10^{3}$ & $3.6 \times 10^{7}$ & $1.6 \times 10^{6} \pm 3.2 \times 10^{5}$ \\
\hline $\mathrm{CC}$ & 139 & 69.5 & $1.5 \times 10^{2}$ & $1.1 \times 10^{5}$ & $3.9 \times 10^{4} \pm 3.9 \times 10^{3}$ \\
\hline TSC & 200 & 100 & $1.0 \times 10^{3}$ & $3.1 \times 10^{6}$ & $5.8 \times 10^{5} \pm 4.8 \times 10^{4}$ \\
\hline
\end{tabular}

$\mathrm{TABC}=$ Total aerobic bacterial Count $(\mathrm{cfu} / \mathrm{ml}), \mathrm{CC}=$ Coliforms Count $(\mathrm{MPN} / \mathrm{ml}), \mathrm{TSC}=$ Total Staphylococci Count $(\mathrm{cfu} / \mathrm{ml})$.

Table (3): Statistical analytical results of bacteriological counts in the examined organic egg content samples $(n=200)$

\begin{tabular}{|c|c|c|c|c|c|}
\hline \multirow{2}{*}{ Bacterial counts } & \multicolumn{2}{|c|}{ Positive Samples } & \multirow{2}{*}{ Min } & \multirow{2}{*}{$\operatorname{Max}$} & \multirow{2}{*}{ Mean \pm SEM } \\
\hline & No & $\%$ & & & \\
\hline TABC & 88 & 44 & $3 \times 10^{2}$ & $1.5 \times 10^{4}$ & $2.7 \times 10^{3} \pm 4 \times 10^{2}$ \\
\hline $\mathrm{CC}$ & 28 & 14 & $4 \times 10$ & $2.3 \times 10^{2}$ & $8.1 \times 10 \pm 1.5 \times 10$ \\
\hline TSC & 54 & 27 & $2 \times 10^{2}$ & $5.7 \times 10^{3}$ & $8.5 \times 10^{2} \pm 1.6 \times 10$ \\
\hline
\end{tabular}

Table (4): Incidence of Staphylococcus aureus in the examined organic hens eggs samples.

\begin{tabular}{|c|c|c|c|}
\hline \multirow{2}{*}{ Samples } & \multirow{2}{*}{$\begin{array}{l}\text { No. of examined } \\
\text { samples }\end{array}$} & \multicolumn{2}{|c|}{ Biochemical Identified S.aureus positive samples } \\
\hline & & No. & $\% *$ \\
\hline Egg shell & 200 & 14 & 7 \\
\hline Egg content & 200 & 0 & 0 \\
\hline
\end{tabular}

*The percentages were calculated according to the total samples number.

Table (5): Incidence of salmonella in the examined organic hens eggs samples.

$\overline{\text { Kafrelsheikh Vet. Med. J. Vol. } 14 \text { No. } 1 \text { (2016) }}$ 


\begin{tabular}{|c|c|c|c|}
\hline \multirow{2}{*}{ Samples } & \multirow{2}{*}{$\begin{array}{c}\text { No. of examined } \\
\text { samples }\end{array}$} & \multicolumn{2}{|c|}{ Biochemical Identified salmonella positive samples } \\
\hline & & No. & $\% *$ \\
\hline Egg shell & 200 & 3 & 1.5 \\
\hline Egg content & 200 & 0 & 0 \\
\hline
\end{tabular}

*The percentages were calculated according to the total samples number.

Table (6): Serogrouping of the Salmonella strains isolated from organic eggs shell.

\begin{tabular}{|c|c|c|}
\hline \multirow[t]{2}{*}{ Serotypes } & \multicolumn{2}{|c|}{ Organic egg shell positve sample } \\
\hline & No & $\% *$ \\
\hline $\begin{array}{c}\mathrm{S} \text {.Gueuletapee } \\
\mathrm{O}_{9,12} \quad \mathrm{H}_{1}: \mathrm{g}, \mathrm{m}, \mathrm{s} \quad \mathrm{H}_{2}:-\end{array}$ & 1 & 33.3 \\
\hline $\begin{array}{c}\mathrm{S} \text {.Enteritidis } \\
\mathrm{O}_{9},{ }_{12} \mathrm{H}_{1}: \mathrm{g}, \mathrm{m} \quad \mathrm{H}_{2}:-\end{array}$ & 1 & 33.3 \\
\hline $\begin{array}{c}\mathrm{S} \text {.Atakpame } \\
\mathrm{O}_{8,20} \mathrm{H}_{1}: \mathrm{e}, \mathrm{h} \mathrm{H}_{2}: 1,7\end{array}$ & 1 & 33.3 \\
\hline
\end{tabular}

*The percentages were calculated according to the total number of salmonella positive samples.

\section{DISCUSSION}

Egg quality has an influence on egg acceptance or rejection by the consumer. Egg quality defects are deviations in external and internal standards of the egg that affect the quality. The external quality characteristics of organic eggs samples showed that $45 \%, 9 \%, 4.5 \%$ had dirty shell, rough shell, and bad odour, respectively (Table 1). Lower percentages were reported by $\boldsymbol{D e} \mathbf{R e u}$, et $\boldsymbol{a l}$. (2009a) who found the percentage of egg shell dirties were 7.1 and Hafez taghreed, et al.(2013) recorded $4 \%, 8 \%, 0 \%$ of the egg shell were dirty, rough and bad odour. 
While higher percentage was reported by De Reu, et al.(2005) that reported $82.5 \%$ of organic egg shell were contaminated with feces and/or blood. Dirty shell decrease the quality of eggs and in some areas ,an egg with manure or adhering material on the shell cannot be marketed and classified as dirty and cannot be used for human consumption (Jacob et al., 2011). Rough shell eggs fracture more easily and have poor appearance and this may be hereditary. Bad odours could be associated with poor storage conditions (long storage period and high temperature), use of strongly flavored ingredients in the feed and may be from chemicals used for treating parasites in the flocks (Jacob et al., 2011). Nine samples out of the examined egg samples had bad odour and not comply with the Egyptian standards (E.O.S.Q, 2007) which stated that the fresh table eggs should be free from bad odours. Concerning to Egyptian standards (E.O.S.Q, 2007) the dirties either collected or separated on egg shell, should not exceed 1/ 32 and 1/16 from the shell surface respectively. Organic hens eggs agree with the Egyptian standard that have dirties below the standard level.

Total aerobic bacterial count (TABC) is a prime consideration in examination of food. It gives numerical figure about the general hygienic quality of food and reflects the sanitary measures adopted during production, handling and storage (ICMSF, 2009). Data recorded in Table (2) revealed the TABC in egg shell ranged from $5.5 \times 10^{3} \mathrm{cfu} / \mathrm{ml}$ to $3.6 \times 10^{7} \mathrm{cfu} / \mathrm{ml}$ with a mean value of $1.6 \times 10^{6} \pm 3.2 \times 10^{5} \mathrm{cfu} / \mathrm{ml}$. Nearly similar result of total aerobic bacterial count of organic egg shell were reported by De Reu, et al.(2005); Hafez Taghreed, et al. (2013) Parisi, 
et al. (2015). While, relatively lower counts were reported by $\mathbf{D e} \boldsymbol{R e u}$, et al. (2009b); Huneau-Salaun (2010); Galis, et al. (2012). Organic eggs and free-range ones revealed the highest values concerning the microbial load of the eggshell. This may be due to contact with exterior environment, the soil as well as the natural factors contributing to an easier contamination of the eggshell. Also, birds that are allowed to range outdoors are more likely to be contaminated from insects and rodent infestation ( Galis, et al. 2012). The high count of TABC on eggs shell revealed unhygienic practice in the farm and unsanitary measures adopted during production, handling and storage. Concerning egg content samples, the TABC was recorded (44\%) of the examined samples. The count ranged from $3 \times 10^{2}$ to $1.5 \times 10^{4} \mathrm{cfu} / \mathrm{g}$ with an average of $2.7 \times 10^{3} \pm 4 \times 10^{2} \mathrm{cfu} / \mathrm{g}$ (Table 3 ). The TABC in eggs content complies with the Egyption standard (E.O.S.Q, 2007) for fresh table egg which stated that TABC in the egg content should not exceed $2.5 \mathrm{x}$ $10^{5} \mathrm{cfu} / \mathrm{g}$.

Coliforms count is the traditional indicator of possible fecal contamination, microbial quality, wholesomeness and reflect the hygienic standards adopted in the food operation. The results presented in (Table 2) revealed that $(69.5 \%)$ out of the examined egg shell samples were contaminated with coliforms with a mean value of $3.9 \times 10^{4} \pm 3.9$ $\mathrm{x} 10^{3} \mathrm{MPN} / \mathrm{ml}$. Considering egg content samples, coliform bacteria were detected in (14\%) of the examined samples with an average of $8.1 \times 10 \pm$ $1.5 \times 10 \mathrm{MPN} / \mathrm{g}$ (Table 3). The obtained results of coliforms in egg shells samples agrees to some extend with those reported by $\mathbf{D e} \boldsymbol{R e u}$, et al. (2006) in which they reported low level of Gram negative organisms on 
the shell of eggs from alternative system. While, lower count from whole egg were reported by Schwaiger, et al.(2008) who isolate coliforms from only single case. The prevalence of coliforms with these incidence may be attributed to the poor hygiene in the resulting areas; consequently such eggs with high coliforms constitute an economic and public health importance (Sabreen, 2001).

Staphylococci are the most commonly human pathogen that contaminates food through food handlers. As between 25 and $50 \%$ of the population may be carriers of staphylococci (ICMSF, 1978). Table (2) illustrated that the mean total staphylococcal count of the egg shell was $5.8 \times 10^{5} \pm 4.8 \times 10^{4} \mathrm{cfu} / \mathrm{ml}$. S. aureus was recorded in $7 \%$ out of the examined egg shell samples (Table 4). Staphylococcus aureus food poisoning is one of the most common types of food borne diseases worldwide, which caused by an intoxication resulting from the ingestion of food containing Staphylococcal enterotoxins, which is emetic, pyogenic, mitogenic, suppresses immunoglobulin secretion and enhances toxic shock (Stewart et al., 2002).

The presence of Staphsylococci in high number of egg shell samples is probably as a result of the dominance of the genus on parts of the human body such as hands, nose, skin and clothing (Nwagu and Amadi, 2010).

Considering egg content, staphylococci were detected in $27 \%$ of the examined samples with an average of $8.5 \times 10^{2} \pm 1.6 \times 10 \mathrm{cfu} / \mathrm{g}$ (Table 3). Staphylococci are the most common bacteria contaminating eggshells. Contamination to content is more likely linked with cracked

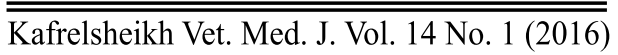


egg, dirty shells and storage in contaminated surroundings. It can be contaminated during formation and laying process (Abdullah, 2010). Elliott (1954) revealed that stored or aged eggs have more possibility to become infected than fresh eggs due to the degradation of natural defense mechanisms in egg over time. The eggshell contamination increasing the chances of egg contents contamination by penetration (Messens, et al. 2006). According to the Egyptian standard of fresh table egg (E.O.S.Q., 2007), eggs should be free from pathogenic microorganisms. All examined eggs content samples were free from $S$. aureus and complied with the recommended standard.

Results presented in table (5) pointed out that three samples of egg shell (1.5\%) had Salmonella spp. Considering egg content samples Salmonella could not be detected in any one. Similar prevalence of salmonellae on the egg shell 2.36\% was recorded by Parisi, et al. (2015). While higher finding was recorded by FSA (2004) who stated that nine samples $34 \%$ were contaminated with salmonella and all positive salmonella were isolated from the egg shell. Galis, et al (2012) could isolate Salmonella from the organic egg content with incidence (33.3\%) present in the albumen. High prevalence of salmonellae on the organic egg production system were reported by Kinde, et al. (1996) ; Methner, et al.(2006); Sapkota, et al. (2014). While Molbak and Neimann (2002) ; Hanninen, (2004); Virtala, et al. (2005); Van de Vijver, et al. (2008); De Reu, et al. (2009a) could not detected salmonellae in organic egg samples. This result did not agrees with the Egyptian standard which states that fresh table eggs should be free from pathogenic microorganisms (E.O.S.Q., 2007). 
As the content of newly laid eggs from healthy hen is nearly sterile and the rate of contamination of produced egg depend mainly on the hygienic measures adopted in the farm or during handling and storage off eggs. Proper farm hygiene, handling and storage are necessary for good quality eggs. In addition, eggs should be stored under refrigeration and raw eggs should not be used in food.

\section{REFERANCES}

- Abdullah, I.N. (2010): Isolation and identification of some bacterial isolates from table egg. Journal of Veterinary Science. 3(2): 59-67.

- A.P.H.A (American Public Health Association) (2004): Standard methods for the examination of dairy products, 17th ed. American public Health Association. Washington DC USA.

- De Reu, K. ;Grijspeerdt, K.; Heyndrickx, M.; Uyttendaele, M. Debevere, J. and Herman, L. (2006): Bacterial eggshell contamination in the production chain of different commercial housing systems. British Poult Sci. 47(2):163-172.

- De Reu, K ; Grijspeerdt, K. ; Heyndrickx, M. ; Uyttendaele, M. and Herman, L. (2005): The use of total aerobic and Gram negative flora for quality assurance in the production chain of consumption eggs. Food Control .16(2):147-155.

- De Reu, K.; Rodenburg, T. B.; Grijspeerdt, K. ;Messens, W.; Heyndrickx, M.; Tuyttens, F. A. M.; Sonck, B. ; Zoons, J.; and Herman, L. (2009b): Bacteriological contamination, dirt, and cracks 
of eggshells in furnished cages and noncage systems for laying hens: An international on-farm comparison. Poultry Sci 88 (11) :2442-2448.

- De Reu, K.; Renders, K.; Maertens, G. ;Messens, W.; Reybroeck, W.; Ooghe, S.; Herman, L. and Daeseleire, E. (2009a): A market study on the quality of eggs from different housing systems. World poultry sci association. XIIIth European Symposium on the quality of eggs and egg products, Turku, Finland. 21-25 June 2009. pp. 1-7.

- E.O.S.Q. (2007): Egyptian organization for standardization and Quality. Fresh table eggs. 3169/2007.

- Elliott, R.P. (1954): Spoilage of shell eggs by pseudomonads. Applied Microbiology. 2 (3) : 158-164.

- FDA (Food and drug agency) (1998a): Bacteriological Analytical Manual, 8th Edition, Chapter 12. Staphylococcus aureus. AOAC international, gaithersburg, USA.

- FDA (Food and drug agency) (1998b): Bacteriological Analytical Manual, 8th Edition, Chapter 4. Salmonella. AOAC international, gaithersburg, USA.

- FSA (Food Standards Agancy) (2004): Report of the survey Salmonella contamination Of UK-produced shell eggs on retailsale. UK food standards agncye,London.http://www.food.gov. uk//science/ surveillance/fsis2004branch/fsis5004egg ?view=printerfi.

- Galis, A. ; Van, I. and Théwis, A. (2012): Organoleptic, chemical and microbiological quality of table eggs obtained from different 
exploitation systems for laying hens in Romania. Scientific Papers, Animal Science, Series D, vol. LV. Page 162-166.

- Hafez taghreed, A. ; EL- ghayaty hanan, A. and Megahed Amal, A. (2013): A comparason between organic and conventionally produced egg Assiut Veterinary Medical Journal. 59 ( 136) : 55-59.

- Hanninen, M.L. (2004): Salmonella and Campylobacter in organic egg production with special reference to the Finnish situation. Proceedings of the 3rd SAFO Workshop, Falenty, Poland, 47-50.

- Harrigan, W.F. (1998): Laboratory Methods in Food Microbiology, $3^{\text {rd }}$ ed. Pub. by Academic Press 525 B Street, Suite 1900, San Diego, California, 92101-4495, USA.

- Henry, R. (2002): Organic poultry-Eggs. Martime certified organic growers. Organic farm profiles.March 2002.

- Huneau-Salaun, A.; Michel, V.; Huonnic, D. and Le Bouquin S. A. (2010): Factors influencing bacterial eggshell contamination in conventional cages, furnished cages and free-range systems for laying hens under commercial conditions. British Poultry Sci 51(2): 163-169.

- I.C.M.S.F. (International Commission of Microbiological Specification for Foods) (1978): Microorganisms in Food, their Significance and Methods of Enumeration. 2nd Ed. Univ. of Toronto, Toronto Press, Ontario, Canada.

- I.C.M.S.F. (International Commission of Microbiological Specification for Foods) (2009): International Committee on Microbiological Specifications for Foods' Microorganisms in food 1, Their Significance and Methods of Enumeration. 2nd Ed., University of Toronto Press, Toronto, Buffalo and London. 
- ISO (International Organization for standardization) (2003): ISO standard DIS 6888:2003 (E). Horizontal method for the enumeration of Coagulase Positive Staphylococci ( $S$. aureus and other species).

- Jacob, J.P.; Miles, R.D. and Ben Mather, F. (2011) :Egg quality. http//:WWW.Edis.ifas.ufl.edu.

- Kinde, H; Read, D.H.; Chin, R.P.; Bickford, A.A.; Walker, R.L.; Ardans, A.; Breitmeyer, R.E.; Willoughby, D.; Little, H.E.; Kerr, D. and Gardner, I.A. (1996): Salmonella enteritidis, phase type 4 infection in a commercial layer flock in southern California: bacteriologic and epidemiologic findings. Avian Dis . 40(3):665-71.

- Kouba, M. (2003): Quality of organic animal products. Livestock Production Science 80 (2003) 33-40.

- Messens, W.; Grijspeerdt, K. and Herman, L. (2006): Eggshell penetration of hen's eggs by Salmonella enteric serovar enteritidis upon various storage conditions. British Poultry Sci. 47 (5): 554-560.s

- Methner, U.; Diller, $R$; Reiche, $R$ and Bohland, K. (2006): Occurence of salmonellae in laying hens in different housing systems and inferences for control. Berl Munch Tierarztl Wochenschr. 119 :467-73.

- Molbak, K., and Neimann, J.(2002): Risk factors for sporadic infection with Salmonella Enteritidis: Denmark, 1997-1999. Am. J Epidemiol. 156:654-661.

- Newerli-Guz, j. and Śmiechowska, M. (2004): Organic food advantages in consumers opinion . bromate. Chem. Toksykol., Suppl., 135-138. 
- Nwagu, T.N. and Amadi, E.C. (2010): Bacterial population of some commercially prepared yoghurt sold in Enugu State, Eastern Nigeria. African Journal of Microbiology Research, 4 (10): 984-988.

- Parisi, M.A.; Northcutt, J.K.; Smith, D.P.; Steinberg, E.L. and Dawson, P.L.(2015): Microbiological contamination of shell eggs produced in conventional and free-range housing systems. Food Control. 47 (2015) :161-165.

- Sabreen, M.S. (2001): Search for some pathogenic bacteria in commercial hens and duck's eggs sold in Assiut Governorate. Assiut Vet. Med. J. 45 (89): 91-103.

- Sapkota, A.R.; Kinney, E.L.; George, A.; Hulet, R.M.; Cruz-Cano R.; Schwab, K.J; Zhang, G. and Joseph, S.W. (2014): Lower prevalence of antibiotic-resistant Salmonella on large-scale U.S. conventional poultry farms that transitioned to organic practices. Sci Total Environ. 1 :387-92.

- Schwaiger, K.; Schmied, E.M. and Bauer, J.(2008): Comparative analysis on antibiotic resistance characteristics of Gram-negative bacteria isolated from laying hens and egg in conventional and organic keeping systems in Bavaria, Germany. Zoonoses Public Health. 55 (7): 331-341.

- Stewart, C.M; Cole, M.B.; Legan, J.D.; Slade, L.;Vandeven, M.H and Schaffner, D.W. (2002) Staphylococcus aureus growth boundaries: moving towards mechanistic predictive models based on solutespecific effects. Appl. Environ. Microbiol., 68(4):1864-1871.

- USDA. (united states department of agriculture) (2009): Organic food standards and labels. The facts. http//www.ams.usda.gav. 
- Vaclavik, V.A. and Christian, E.W. (1998): Essential of food science,1st, Ed. International Thmson Publishing. New York .London.

- Van de Vijver, L.P.L.; Hoogenboom, A.P.;Broex, N.J.G.; van der Roest, J; Bokhorst, J.G.; Northolt, M.D. ; Mevius, D. and Meijs, J.A.C. (2008): Contaminants and microorganisms in Dutch organic food products: A comparison with conventional product. Food Addit Contam Part A Chem Anal Control Expo Risk Assess. 25(10): 1195-207.

- Virtala, A.; Holma, U.; Hovi, M. ; Hanninen, M. ; Hyyrynen, T.; Rossow, L; Kahiluoto, H. and Valros, A. (2005): Systems SAFO Workshop 17-19 March 2005, Frick, Switzerland. sArchived at http://orgprints.org/5965.

در اسة عن جودة بيض الدجاج الحيوي في السوق المصري

أجريت هذه الدراسـة علي البيض الحيوي في السوف المصري بهدف تقييم الخواص الطبيعية

والمحتوي الميكروبي وقد أظهرت الدراسة أن نسبة القشرة المنسخة ؛القشرة الخشنة؛ والقشرة ذات الرائحة الكريهة هي 45\%؛ 9\%؛ 5.5\% . كمـا أوضـحت الدراسـة أن متوسط العدد الكلى لكل مـن البكتريـا

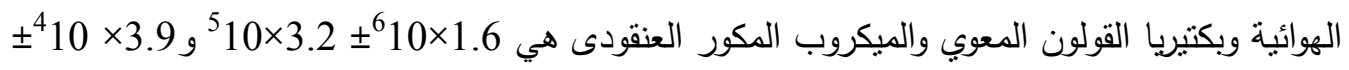

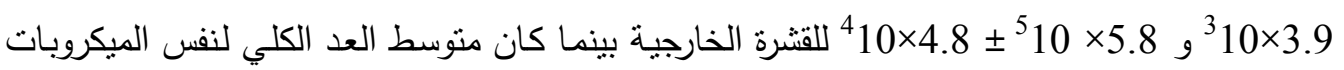

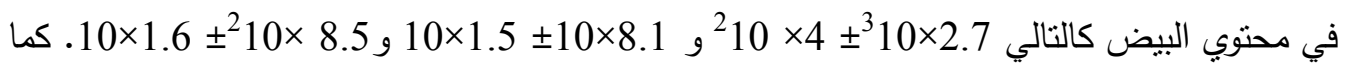
تم عزل كل من ميكروب المكور العنقودى الزهبي وميكروب السـالمونيلا من 7\% و 1.5 \% من 
عينات القثرة الخارجية. هذا وقد تم مناقثـه الأهمية الاقتصادية والصحية لوجود هذه الميكروبات في البيض الحيوي. 